\title{
Synovial sarcoma: case report
}

\author{
Sarcoma sinovial: relato de caso
}

\author{
Isabella Lima Arrais RIBEIRO' \\ Larissa Cavalcanti MONTEIRO' \\ Ana Carolina Rodrigues de MELO' \\ Tácio Candeia LYRA ${ }^{1}$ \\ Julio Cesar Campos FERREIRA FILHO² \\ Alexandre Rolim da PAZ ${ }^{3}$ \\ Paulo Rogério Ferreti BONAN ${ }^{4}$ \\ Ana Maria Gondim VALENÇA ${ }^{4}$
}

\section{ABSTRACT}

Introduction: Synovial sarcomas are rare and aggressive neoplasms located in the head and neck region and usually occurs in young adults. Presentation of case: This report presents a case of synovial sarcoma in a 15-year-old male patient who sought medical treatment for painful symptoms and associated dysphagia. The lesion was nodular, extensive, localized in the parotid region, and extended to the left cervical region. The patient was treated in a referral hospital with a treatment protocol that initially included chemotherapy for six months and surgery to attempt to excise the lesion, but the surgery was ineffective because removal could have damaged important vital structures. The Computed Tomography scan showed a hypodense area with diffuse growth and no involvement of the facial bones and the histopathological analysis revealed pleomorphic and oval spindle cells with rounded epithelial cells that formed nests surrounded by fibrous tissue. The Immunohistochemistry analysis was conclusive for the diagnosis of a high-grade SS in the parotid and left cervical regions. The medical team opted for palliative treatment with cervical radiotherapy. The patient remained hospitalized for four months after the surgery and died after 15 months since the diagnosis for compromise of airway by fast tumor growth. Conclusion: The synovial sarcoma, when diagnosed late may reduce the survival of patients because of the complications that tumor growth can bring to the prognosis and quality of life.

Indexing terms: Induction chemotherapy. Neoplasms. Synovial sarcoma.

\section{RESUMO}

Sarcomas sinoviais são neoplasias raras e agressivas, localizadas na região da cabeça e pescoço e geralmente ocorrem em adultos jovens. Relato do caso: este relato apresenta um caso de sarcoma sinovial em um paciente de 15 anos que procurou tratamento médico para sintomas dolorosos e associados à disfagia. A lesão era nodular, extensa, localizada na região da parótida e estendida à região cervical esquerda. 0 paciente foi tratado em um hospital de referência com um protocolo de tratamento que inicialmente incluiu quimioterapia por seis meses e cirurgia para tentar excisar a lesão, mas a cirurgia foi ineficaz porque a total remoção do tumor poderia comprometer estruturas vitais importantes. A tomografia computadorizada mostrou uma área hipodensa com crescimento difuso, sem envolvimento dos ossos faciais, e a análise histopatológica revelou células fusiformes pleomórficas e ovais, com células epiteliais arredondadas formando ninhos rodeados por tecido fibroso. A análise imunohistoquímica foi conclusiva para o diagnóstico de um sarcoma sinovial de alto grau na região cervical parotídea esquerda. A equipe médica optou pelo tratamento paliativo com radioterapia cervical. O paciente permaneceu hospitalizado por quatro meses após a cirurgia e faleceu 15 meses após o diagnóstico, devido à obstrução das vias aéreas pelo rápido crescimento tumoral residual. O sarcoma sinovial, quando diagnosticado tardiamente pode reduzir a sobrevida dos pacientes por causa de complicações que o crescimento do tumor pode trazer para o prognóstico e qualidade de vida.

Termos de indexação: Quimioterapia de indução. Neoplasias. Sarcoma sinovial.

\section{INTRODUCTION}

Synovial sarcomas (SSs) are rare and aggressive neoplasms that account for $5-10 \%$ of soft tissue neoplasms ${ }^{1}$, only $3 \%$ of which are located in the head and neck region ${ }^{2}$. This neoplasm usually occurs in young adults and is typically found close to the joints of the upper and lower extremities without synovial membrane involvement ${ }^{3}$. SSs are thought to originate from ordinary mesenchymal or specialized arthrogenic tissue $e^{4-5}$.

A diagnosis of SS is dependent on a histological and immunohistochemical study. A histological analysis can identify four subtypes of SS: biphasic, monophasic spindle cell, monophasic epithelial, and poorly differentiated, of which the biphasic subtype is the most common ${ }^{6}$. Upon immunohistochemical examination, SSs express epithelial

\footnotetext{
${ }^{1}$ Universidade Federal da Paraíba, Centro de Ciências da Saúde, Programa de Pós-Graduação em Odontologia. Cidade Universitária, 58051-900, João Pessoa, PB, Brasil. Correspondência para / Correspondence to: ILA RIBEIRO. E-mail: <isabella_arrais@yahoo.com>.

2 Universidade Federal do Rio de Janeiro, Programa de Pós-Graduação em Odontologia. Rio de Janeiro, RJ, Brasil.

3 Hospital Napoleão Laureano, João Pessoa, PB, Brasil.

${ }^{4}$ Universidade Federal da Paraíba, Centro de Ciências da Saúde - Campus I, Departamento de Odontologia Clínica e Social. João Pessoa, PB, Brasil.
} 
(cytokeratin and epithelial membrane antigen (EMA)) and mesenchymal (vimentin) markers ${ }^{5}$.

The treatment of choice for this type of tumor is surgical excision with a wide safety margin whenever possible because the effectiveness of other supporting treatments, such as chemotherapy and radiation therapy, has not been established ${ }^{7}$.

This article describes the clinical, computed tomographic, histopathological, and immunohistochemical findings of a high-grade SS in the parotid and cervical region.

\section{CASE REPORT}

A brown-skinned, 15-year-old male patient arrived at the paediatric oncology unit of the Hospital Napoleão Laureano (João Pessoa-Paraíba) complaining of a "lump on his face" with painful symptoms and associated dysphagia (Figure 1). In the anamnesis, the patient reported having good general health, with no significant prior illnesses. An ectoscopy showed a nodule in the parotid and left cervical regions, presenting with a hyperaemic halo due to the appearance of the lesion, which first appeared two months previously and grew rapidly. However, the patient only sought medical attention after being alerted by health professionals at a home visit when the lesion was already quite large. The patient had no previous reports of lymphadenopathy. A nasal endoscopy did not reveal any noteworthy findings. Given these clinical findings, the following diagnostic hypotheses were considered: fibrosarcoma and chondrosarcoma.

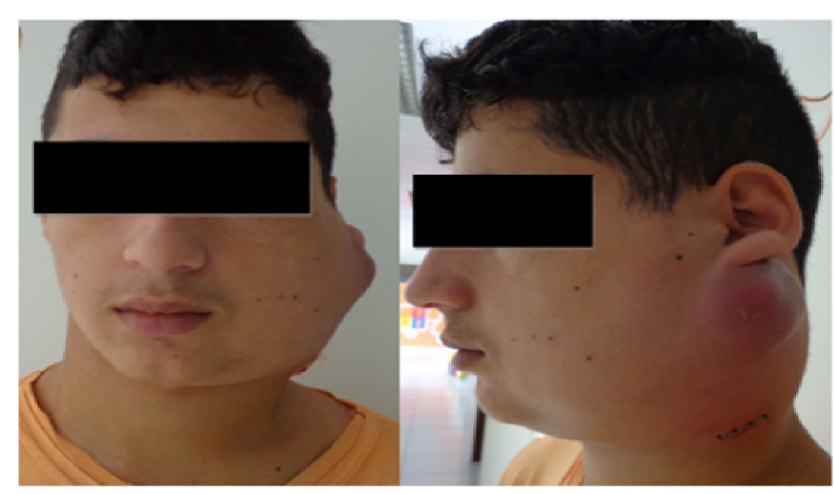

Figure 1. Patient after the initial incisional biopsy performed during diagnostic tests

Axial image at the level of the maxillary sinus of a conventional CT scan showed a hypodense area with diffuse growth and no involvement of the facial bones (Figure 2). An incisional biopsy and histopathological analysis with hematoxylin and eosin (HE) stained sections was performed at 400X magnification, revealing pleomorphic and oval spindle cells with rounded epithelial cells that formed nests surrounded by fibrous tissue. An intense cellular pleomorphism and hyperchromasia were also present (Figure 3)

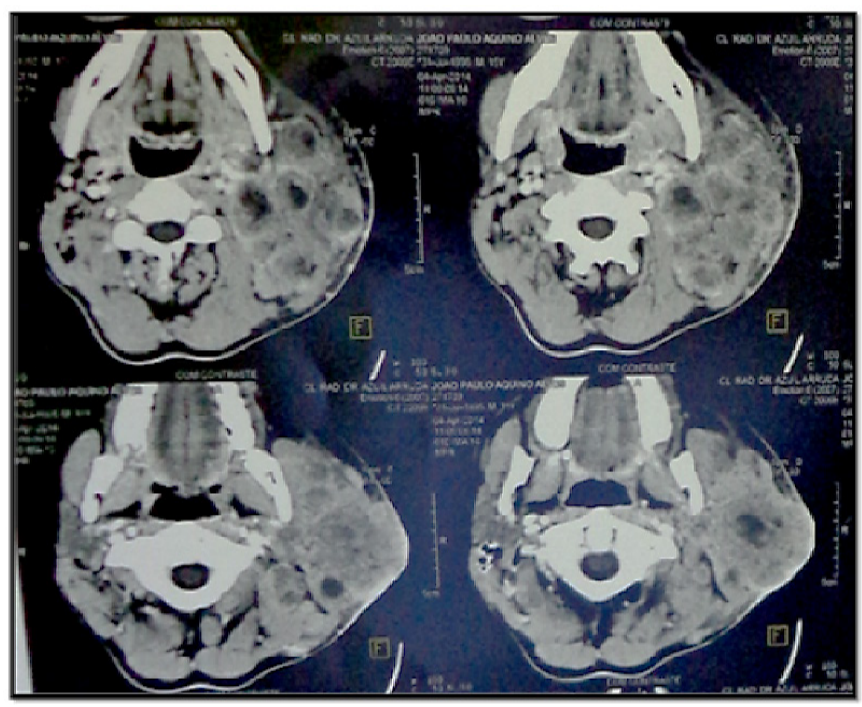

Figure 2. Conventional tomography image. Axial image. Hypodense area with diffuse growth and no involvement of the facial bone.

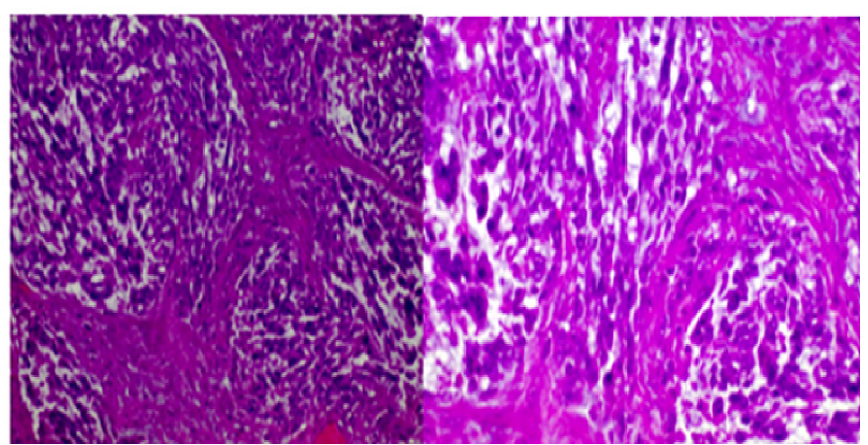

Figure 3. Histopathology of the incisional biopsy of the lesion (Hematoxylin-Eosin staining, original magnification, $x 200$ and $\times 400$ ) showing intense cellular pleomorphism in the shape of nests surrounded by fibrous tissue and hyperchromasia.

Immunohistochemistry was required for the diagnosis and revealed sections that showed intensely positive staining for vimentin and diffuse staining in epithelial cells, cytoplasmic/membrane staining for EMA, TLE-1, CD99-positive staining in the membranes of rounded cells, and $\mathrm{Bcl}$-2-positive staining involving the membranes and cytoplasm, (Figure 4) which is a conclusive diagnosis for a high-grade SS in the parotid and left cervical regions. The positive and negative results can be seen in Table 1. 


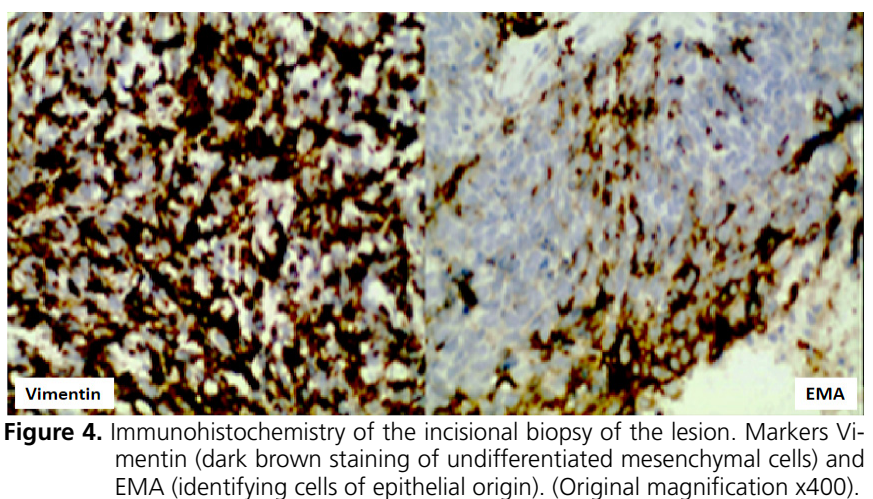

Table 1. Tumor markers involved in immunohistochemical for accuracy in diagnostic of present case.

\begin{tabular}{lc}
\hline Antibody & Reaction \\
\hline Pan cytoqueratin & Negative \\
Desmin & Negative \\
Vimentin & Positive \\
Osteonectin & Negative \\
TLE-1 & Positive \\
EMA & Positive \\
CD99 & Positive \\
BCl-2 & Positive \\
\hline
\end{tabular}

The patient was then treated with chemotherapy (Ifosfamide (4500 mg IV D1 to D4 - $500 \mathrm{ml}$ of SG5\%), Mitexan (1500 mg - $200 \mathrm{ml}$ of SG5\%), and Adriblastina (45 mg IV - $500 \mathrm{ml}$ of SG5\%)) for six months, resulting in a reduction in the tumor volume (Figure 5). After this period, surgery was performed in an attempt to excise the lesion, but due to the extended involvement of important vital structures including major blood vessels in the lesion, it was not possible to completely remove the tumor or even a margin of safety around it because uncontrollable bleeding would have been inevitable.

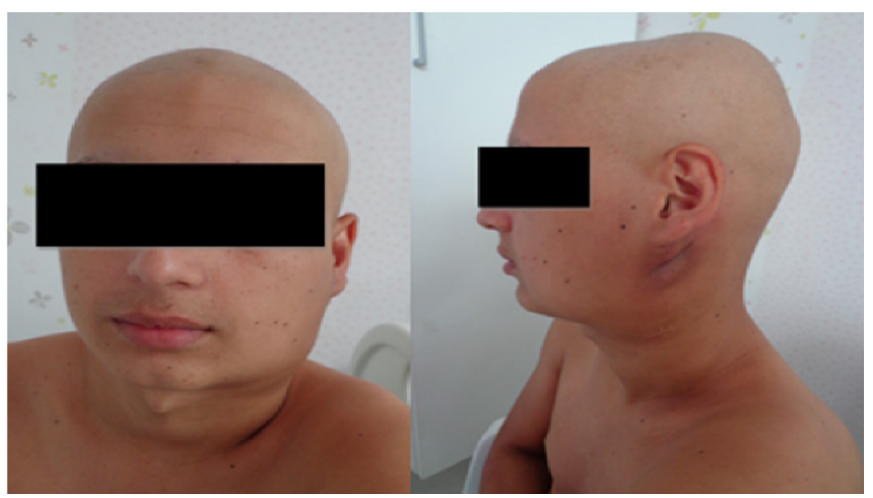

Figure 5. Patient after the course of chemotherapy.
After surgery, the medical team opted for palliative treatment with cervical radiotherapy (20 fractions of radiotherapy (50.4 Gy)).

The patient remained hospitalized for four months after the surgery and died after 15 months since the diagnosis for compromise of airway by fast tumor growth.

\section{DISCUSSION}

The Synovial Sarcoma is a malignant neoplasm rarely found in the head and neck region; only 3-5\% of all sarcomas that arise at this site are SSs. The most common sites in the head and neck region are the hypopharyngeal and parapharyngeal spaces. Generally, this tumor is most often found in the deep soft tissues near the joints of the lower limbs ${ }^{1,5-6}$. An analysis of 36 cases of SSs that involve the head region revealed a high prevalence in parotid locations (14 of 36 cases) $)^{7}$. Salcedo-Hernandez et al. ${ }^{8}$ analysed 16 cases of SS involving the head and neck region, and of these, two were in the parotid region, as in the present study.

The clinical presentation of sarcoma varies depending on the size and location of the lesion. Initially, the patient may complain of pain, swelling, tenderness, and/or limited movement ${ }^{9}$. This painless mass is usually slow growing, as observed in the case of the patient reported here. The overlying skin most often appears normal ${ }^{5}$, but in this case report, the patient reported the presence of intense hyperemic skin since the start of the process.

An accurate and early diagnosis of the tumor lesion is therefore necessary. However, a clinical inspection and the signs and symptoms reported by the patient are not sufficient for a correct diagnosis. Additional tests, especially immunohistochemistry tests, are essential and complement tomographic and histopathological findings, primarily regarding planning for further treatment. In this case, imaging exams (CT scan) and immunohistochemistry and histopathology tests were performed.

The immunohistochemical analysis showed strong reactivity for keratin in epithelial areas and often in spindle cells. SSs are also positive for EMA, vimentin, BCL-2, CD99, and calponin, which facilitates arriving at a correct and conclusive diagnosis of the tumor ${ }^{10}$. The immunohistochemistry techniques performed in this case revealed sections that showed intensely positive staining for vimentin and diffuse staining in epithelial cells, cytoplasmic/membrane staining for EMA, CD99- 
positive staining in the membrane of rounded cells, and $\mathrm{Bcl}$-2-positive staining involving the membrane and cytoplasm. In special situations, vimentin, a mesenchymal tissue marker, is expressed in neoplastic cells of epithelial origin when they lose their three-dimensional orientation. This expression is accompanied by a loss of adhesion molecules and is associated with invasive breast, bladder, and cervical carcinomas ${ }^{11}$. EMA, also known as episialin, is a useful protein for classifying tumors of epithelial origin ${ }^{12}$. The expression of the marker CD99 has been reported in spindle cell neoplasms of connective tissue such as SSs, and increased expression of $\mathrm{BCl}-2$ is correlated with numerous favorable prognostic factors ${ }^{13}$; however, although $\mathrm{BCl}-2$ was positive in the case reported here, the patient's prognosis is unfavorable.

The histological sections were stained with hematoxylin and eosin, revealing pleomorphic and oval spindle cells with rounded epithelial cells that form nests surrounded by fibrous tissue. The classic form of SS exhibits a biphasic pattern composed of two cell populations: epithelial cells and spindle cells. The epithelial cells form nests, gland-like structures, and line slit-like spaces and have abundant eosinophilic cytoplasm ${ }^{14}$.

About $40.0 \%$ of synovial sarcomas produce metastasis, most generally in the long bones and lymph nodes $^{1-3}$. In this case, there locoregional tumor infiltrating the cervical region. The treatment of choice for SSs is still unclear; however, surgical excision of the lesion in combination with adjuvant treatments is considered a suitable choice for the treatment of the tumor, resulting in a reasonable survival rate ${ }^{15}$. The patient reported here underwent chemotherapy for six months, and soon after the chemotherapy treatment, a surgical procedure was performed in which a section of the lesion could not be removed due to the involvement of underlying structures. The medical team opted for palliative treatment with cervical radiotherapy and the patient remained hospitalized for four months after the surgery and died for compromise of airway by fast tumor growth.

In cases such as that discussed here, chemotherapy is administered before and after the tumor resection, especially when as in this case, the total surgical tumor excision is not possible because of the involvement of vital structures such as the carotid artery which could be damaged in an attempt to excision throughout the tumor mass. Chemotherapy performed after surgery works by controlling the growth of tumor mass and preventing the formation of metastatic islands. However, in this case, the chemotherapy, alone, was unable to control the growth of the tumor which, extending towards the median region committed to air passage through the patient's airway.

The survival rate related to SSs is $90,0 \%$ in stage I, $81,0 \%$ in stage II and $56,0 \%$ in stage III. In stage IV the survival is about of $40,0 \%$ in young patients and with smaller tumors than $5 \mathrm{~cm}^{7,10,15}$. In addition, histologic variant of calcifying type of SSs frequently have better survival rate than the type of the case.

One should take into account the tumor stage, which in this case was the type, meeting the patients when the diagnosis in a large tumor growth stage. The family of the patients reported difficulty in the medical access and diagnosis, because they have been given prior diagnosis of mumps, dental abscess and tumor odontogenic until forward the patients to that hospital, which only then the patient was diagnosed with use of appropriate resources ${ }^{16}$.

Often the delay in diagnosis contributes to the rapid growth of tumors in children and adolescents because of the rapid growth of cancers in these age groups ${ }^{17}$. Adds to the failure in the treatment of this case the difficulty of monitoring the vital structures involved by the tumor mass as well as the inability to remove it in its entirety surgically, which could have increased the chances of survival for the patient ${ }^{18}$.

Thus, it can be infer that the synovial sarcoma when diagnosed late in the cervical region may reduce the survival of patients because of the complications that tumor growth can bring to the prognosis and quality of life ${ }^{10,15-16}$.

\section{CONCLUSION}

The SS, when diagnosed late may reduce the survival of patients because of the complications that tumor growth can bring to the prognosis and quality of life.

\section{Collaborators}

ILA RIBEIRO, study concept, writing the paper. LC MONTEIRO, writing the paper. ACR MELO, writing the paper. TC LYRA, writing the paper. JCC FERREIRA FILHO, data collection. AR PAZ, immunohistochemica analyzes. PRF BONAN, review and approval of final version. AMG VALENÇA, review and approval of final version. 


\section{REFERENCES}

1. Banito A, Tasdemir N, Ladanyi M, Lowe SW. Defining epigenetic vulnerabilities in synovial sarcoma. Cancer Res. 2015;75(15 Supplement):2866.

2. Nielsen TO, Poulin NM, Ladanyi M. Synovial sarcoma: recent discoveries as a roadmap to new avenues for therapy. Cancer Discov. 2015;5(2):124-134. doi: 10.1158/2159-8290.CD-141246

3. Ishiki H, Miyajima C, Nakao K, Asakage T, Sugasawa MD, Motoi T. Synovial Sarcoma of the head and neck: rare case of cervical metastasis. Head Neck. 2009; 31(1):131-5. doi: 10.1002/ hed.20856

4. Dilci A, Duzlu M, Yilmaz M, Ozen IO, Pinarl FG. A rare pediatric malignant neck mass: Synovial sarcoma. Egypt J Otolaryngol. 2016;32(3):232. doi: 10.4103/1012-5574.186537

5. Harb WJ, Luna MA, Patel SR, Ballo MT, Roberts DB, Sturgis EM. Survival in patients with synovial sarcoma of the head and neck: association with tumor location, size, and extension. Head Neck. 2007;29:731-40. doi: 10.1002/hed.20564

6. Rigante M, Visocchi M, Petrone G, Mule A, Bussu F. Synovial sarcoma of the parotid gland: A case report and review of the literature. Acta Otorhinolaryngolltal. 2011;31(1):43-6.

7. Al-Daraji W, Lasota J, Foss R, Miettinen M. Synovial sarcoma involving the head: analysis of 36 cases with predilection to the parotid and temporal regions. Am J Surg Pathol. 2009;33(10):1494-1503.

8. Salcedo-Hernández RA, Lino-Silva LS, Luna-Ortiz K. Synovial sarcomas of the head and neck: Comparative analysis with synovial sarcoma of the extremities. Auris Nasus Larynx. 2013;40(5):476-80. doi: 10.1016/j.anl.2012.11.015

9. Foreman SM, Stahl MJ. Biphasic synovial sarcoma in the cervical spine: Case report. Foreman and Stahl Chiropr Man Therap. 2011;19:12. doi: 10.1186/2045-709X-19-12

10. Mattavelli D, Miceli R, Radaelli S, Mattavelli F, Cantù G, Barisella $M$, et al. Head and neck soft tissue sarcomas: prognostic factors and outcome in a series of patients treated at a single institution. Ann Oncol. 2013;24(8):2181-9. doi: 10.1093/annonc/mdt126
11. Nicolazzo C, Gradilone A. Significance of circulating tumor cells in soft tissue sarcoma. Anal Cell Pathol. 2015(2015):697395: 1-6. doi: 10.1155/2015/697395

12. O'Neill JP, Bilsky MH, Kraus, D. Head and neck sarcomas: epidemiology, pathology, and management. Neurosurg Clin N Am. 2013;24(1):67-78. doi: 10.1016/j.nec.2012.08.010

13. Magro G, Longo FR, Angelico G, Spadola S, Amore FF, Salvatorelli L. Immunohistochemistry as potential diagnostic pitfall in the most common solid tumors of children and adolescents. Acta Histochem. 2015;117(4-5):397-414. doi: 10.1016/j. acthis.2015.03.011

14. Akerman $M$, Willen $H$, Carlen $B$, Mandahl N, Mertens F. Fine needle aspiration (FNA) of synovial sarcoma a comparative histological- cytological study of 15 cases, including immunohistochemical, electron microscopic and cytogenetic examination and DNA-ploidy analysis. Cytopathology. 1996,7:187-200. doi: 10.1046/j.1365-2303.1996.38782397.x

15. Freire GSM, Miranda PC, Lopes RAF, Michels DS, Queiroz AL, Nascimento LA. Sarcoma sinovial cervical. Rev Bras Cir Cabeça Pescoço. 2014;43(3):147-9.

16. Brennan MF, Antonescu CR, Alektiar KM, Maki RG. Synovial sarcoma. 2 ed. Springer: Suiça; 2016.

17. Jin SL, Hahn SM, Kim HS, Shin YJ, Kim SH, Lee YS, et al Symptom Interval and Patient Delay Affect Survival Outcomes in Adolescent Cancer Patients. Yonsei Med J. 2016;57(3):572579. doi: 10.3349/ymj.2016.57.3.572

18. Tudor-Green B, Ricardo G, Peter AB. Current update on the diagnosis and management of head and neck soft-tissue sarcomas. J Oral Pathol Med. 2017; 46(1):154-160. 